\title{
Proizvodnja sintetičkog granuliranog amonijeva sulfata
}

\author{
N. Zečević,a* M. Ljubičić,a J. Bjelić,a H. Lisaca i S. Valkov \\ a Petrokemija d. d., Proizvodnja mineralnih gnojiva, 44320 Kutina \\ b SNC Lavalin, 1050 Bruxelles, Belgija
}

\section{|| Sažetak}

Prema izvornoj izvedbi postrojenje za proizvodnju granuliranih kompleksnih mineralnih gnojiva NPK i MAP, koje se nalazi u sastavu proizvodnih postrojenja Petrokemije d. d., nije bilo predviđeno za proizvodnju sintetičkog granuliranog amonijeva sulfata. Prenamjenom postrojenja u dijelu sekcije cijevnog reaktora i rotirajućeg bubnja granulatora uz uporabu sumporne kiseline i tekućeg amonijaka omogućena je proizvodnja sintetičkog granuliranog amonijeva sulfata. S obzirom na izniman egzoterman i korozivan potencijal reakcije neutralizacije amonijaka i sumporne kiseline, vlastitim znanjem razvijen je posebno izveden cijevni reaktor koji omogućava siguran i kontinuirani rad s kapacitetom proizvodnje $20 \mathrm{th}^{-1}$. Uz primjenu cijevnog reaktora razvijen je postupak uporabe i doziranja posebnog aditiva koji omogućava postupak granulacije, s obzirom da bez toga amonijev sulfat nije moguće prevesti u granulirani oblik. Dobivene kemijsko-fizikalne značajke amonijeva sulfata iznimno su zadovoljavajuće u usporedbi s drugim kompleksnim mineralnim gnojivima na bazi dušika. Granulirani amonijev sulfat dobiven inovativnim postupkom proizvodnje svrstan je kao novi proizvod u komercijalni program kompleksnih mineralnih gnojiva Petrokemije d. d., s posebnim naglaskom na mogućnost njegove uporabe u postupcima miješanja s drugim jednostavnim mineralnim gnojivima.

\| Ključne riječi

Aditiv, amonijev sulfat, cijevni reaktor, granulacija

\section{Uvod}

Industrijska proizvodnja sintetičkog amonijeva sulfata postaje popularna početkom 20. stoljeća nakon omogućavanja komercijalne proizvodnje amonijaka u većim količinama. ${ }^{1} \mathrm{~S}$ industrijskim onečišćenjem zraka, vode i tla sumporovim oksidima koji postaju izvor sumpora biljkama te zbog intenzivnije primjene mineralnih gnojiva s većim sadržajem dušika (kao što su urea, amonijev nitrat i njihova međusobna kombinacija), uporaba amonijeva sulfata sve više se smanjuje. Kemijska sinteza amonijeva sulfata vrlo je jednostavna i rezultat je intenzivne egzotermne reakcije neutralizacije sumporne kiseline i amonijaka: ${ }^{2}$

$$
\begin{gathered}
2 \mathrm{NH}_{3}(\mathrm{~g})+\mathrm{H}_{2} \mathrm{SO}_{4}(\mathrm{l}) \rightarrow\left(\mathrm{NH}_{4}\right)_{2} \mathrm{SO}_{4}(\mathrm{~S}) \\
\Delta H=-2091,45 \mathrm{~kJ} \mathrm{~kg}^{-1}
\end{gathered}
$$

Reakcija unutar cijevnog reaktora zbog velike brzine dovodi do nastajanja amonijeva bisulfita, dok se naknadna pretvorba do amonijeva sulfata provodi u rotirajućem bubnju granulatora uz dodatak minimalnih količina amonijaka i sumporne kiseline. ${ }^{3,4}$ Toplina koja se razvija egzotermnom reakcijom neutralizacije amonijaka i sumporne kiseline dovoljna je za isparavanje oko 0,7 tona vode za svaku tonu proizvedenog amonijeva sulfata, što proces čini iznimno atraktivnim u pogledu potrošnje otpadnih vodenih tokova koji sadrže amonijak i sumpornu kiselinu kao onečišćujuće

\footnotetext{
* Autor za dopisivanje: Nenad Zečević, dipl. inž

e-pošta: nenad.zecevic@petrokemija.hr
}

tvari. ${ }^{3,4}$ Amonijev sulfat sadrži dušik ( $w=21 \%$ ) i sumpor $(w=24 \%)$ koji su potpuno topljivi u vodi i prema tome lako dostupni biljci. Sa sve ubrzanijim razvojem poljoprivrede te primjenom najboljih raspoloživih tehnika u proizvodnji kompleksnih mineralnih gnojiva s ciljem smanjenja emisije sumporovih oksida u zrak, dolazi do sve većeg nedostatka dostupnog sumpora u tlu. Sukladno dobroj poljoprivrednoj praksi biljkama je potreban omjer dušika i sumpora u području od $10: 1$ do $5: 1$. Nedostatak sumpora u najvećem dijelu uzrokuje negativne učinke u izgradnji aminokiselina koje sadrže sumpor, kao što su cistein i metionin. ${ }^{5,6,7,8}$ Osim toga, sumpor sudjeluje u procesu fotosinteze, a u nekim slučajevima može poboljšati vezanje dušika iz atmosfere. ${ }^{8}$ Za razliku od sulfatnih iona koji su odmah dostupni biljkama, elementarni sumpor mora se oksidirati pomoću bakterija, što znatno otežava proces asimilacije u procesu izgradnje proteina. Sintetički granulirani amonijev sulfat, za razliku od kristalnog oblika, posjeduje iznimno malu higroskopnost, dobra fizikalna svojstva i kemijsku stabilnost te agronomsku učinkovitost. Trenutačno se u svjetskim okvirima amonijev sulfat proizvodi u kristalnom obliku kao sporedni proizvod prilikom proizvodnje kaprolaktama te pranjem otpadnih plinova sumpornom kiselinom pri proizvodnji čelika u visokim pećima. ${ }^{1}$ Za razliku od kristalnog amonijeva sulfata, granulirani oblik s karakterističnim oblikom granula iznimno je pogodan za postupke miješanja $s$ drugim jednostavnim mineralnim gnojivima, što znatno povećava ekonomsku primjenu mineralnih gnojiva u poljoprivrednoj proizvodnji. S obzirom na pogodnosti miješanja jednostavnih granuliranih mineralnih gnojiva umjesto primjene kompleksnih gotovih proizvoda te s ciljem uvođenja novog proizvoda u proces proizvodnje 
koji bi omogućio kontinuirani rad postrojenja za proizvodnju sumporne kiseline, Petrokemija d. d. je prenamjenom postojećeg postrojenja za proizvodnju granuliranih kompleksnih mineralnih gnojiva NPK (dušik, fosfor, kalij) i MAP (monoamonijev fosfat) uspješno proizvela sintetički granulirani amonijev sulfat.

\section{Eksperimentalni dio}

Postrojenje za proizvodnju kompleksnih mineralnih gnojiva NPK i MAP projektirano je prema licenciji Fisons Ltd. s mogućnošću proizvodnje $55 \mathrm{th}^{-1}$. Glavne sirovine za proizvodnju su fosforna kiselina, sumporna kiselina, tekući amonijak, kalijev klorid, kalijev sulfat i drugi izvori dušika, fosfora, kalija i sumpora koji se mogu upotrebljavati u proizvodnji kompleksnih mineralnih gnojiva. Postupak proizvodnje provodi se u predneutralizatoru i/ili cijevnom reaktoru pomoću rotirajućeg bubnja granulatora, rotirajućeg bubnja sušionika, rotirajućeg bubnja hladnjaka, sustava pranja otpadnih plinova, sustava sita, otprašivanja i transporta. Gotovi proizvodi posjeduju sve potrebne fizikalno-kemijske značajke nužne za komercijalnu primjenu.

Osnovne promjene unutar postojećeg postrojenja provedene s ciljem proizvodnje sintetičkog granuliranog amonijeva sulfata bile su sljedeće:
1. izrada materijalno-energijske bilance svih medija uključenih u proces proizvodnje, s posebnim naglaskom na odvođenje topline egzotermne reakcije

2. rekonstrukcija cijevnog reaktora s ciljem postizanja odgovarajuće geometrije te odabir odgovarajućeg materijala otpornog na iznimno egzotermnu i korozivnu reakcijsku smjesu tekućeg i/ili plinovitog amonijaka i sumporne kiseline,

3. novi sustav dodavanja aditiva za provođenje procesa granulacije,

4. promjene u postavkama instrumentno-regulacijske opreme (ventili, mjerila protoka, tlaka i temperature)

5. promjene u sustavu otprašivanja, sita i transporta.

Tijekom proizvodnje sintetičkog granuliranog amonijeva sulfata ispitivana su njegova sljedeća fizikalno-kemijska svojstva: maseni udjel dušika, maseni udjel sumpora, $\mathrm{pH}$, granulometrijski sastav, čvrstoća, maseni udjel prašine, stvrdnjavanje, vlaga, habanje i nasipna gustoća.

Na slici 1 prikazana je osnovna blok-shema izvorno izvedenog sustava za proizvodnju kompleksnih granuliranih mineralnih gnojiva NPK i MAP, dok je na slici 2 prikazana blok-shema na kojoj su naznačene promjene koje su omogućile proizvodnju sintetičkog granuliranog amonijeva sulfata.

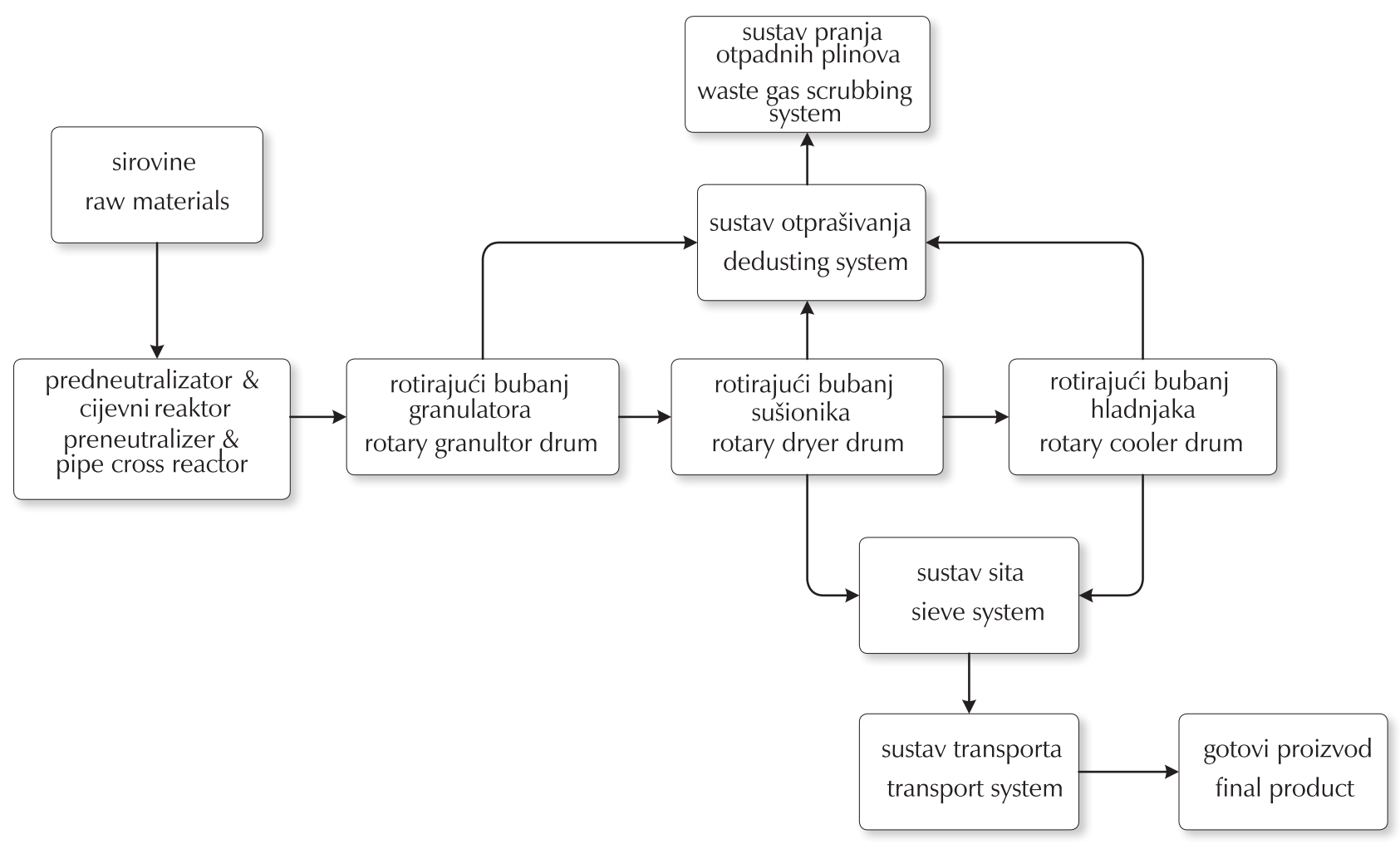

Slika 1 - Blok-shema prenamijenjenog postrojenja za proizvodnju sintetičkog granuliranog amonijeva sulfata

Fig. 1 - Block diagram of the plant for production of complex mineral NPK and MAP fertilizers 


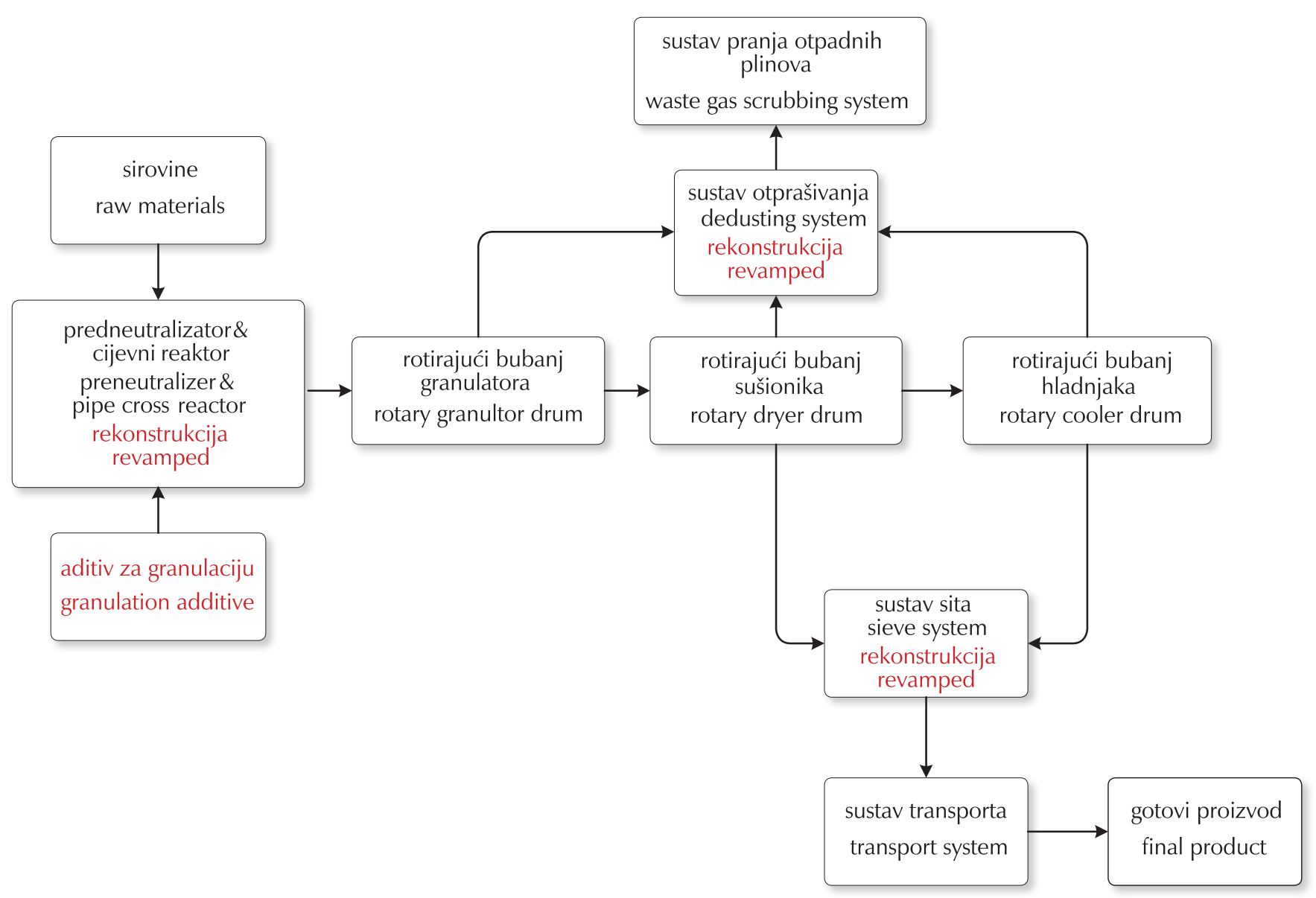

Slika 2 - Blok-shema prenamijenjenog postrojenja za proizvodnju sintetičkog granuliranog amonijeva sulfata

Fig. 2 - Block diagram of the revamped plant for production of synthetic granulated ammonium sulphate

\section{Rezultati i rasprava}

Od ukupne svjetske količine amonijeva sulfata koji se upotrebljava u poljoprivrednoj proizvodnji njegov najveći dio nastaje kao sporedni proizvod prilikom proizvodnje metil-metakrilata, kaprolaktama te pri proizvodnji čelika. ${ }^{1}$ Amonijev sulfat proizveden na navedeni način u obliku je sitnih kristalića manjih od $0,1 \mathrm{~mm}$ i iznimno sklonih stvrdnjavanju, što uzrokuje njegovu otežanu primjenu u poljoprivrednoj proizvodnji. Osim navedenog nedostatka, tako dobiven proizvod onečišćen je teškim metalima (npr. niklom), koji negativno utječu na razvoj različitih poljoprivrednih kultura. Zbog sve učestalije primjene postupaka miješanja jednostavnih mineralnih gnojiva u poljoprivrednoj proizvodnji, pri čemu amonijev sulfat pokazuje iznimnu kompatibilnost s gotovo svim jednostavnim mineralnim gnojivima (kao što su amonijev nitrat, urea, MAP/DAP, kalijev klorid, i dr.), pojavljuje se sve veća potreba za proizvodnjom amonijeva sulfata u obliku granula veličine od 2 do $5 \mathrm{~mm}$. Navedeni granulometrijski sastav, uz zadovoljavajuće ostale fizikalne značajke olakšava postupak namješavanja kao iznimno atraktivan postupak proizvodnje, posebice u ekonomskom pogledu. $\mathrm{S}$ obzirom na to da su pojedina postrojenja unutar proizvodnog kompleksa za proizvodnju mineralnih gnojiva Petrokemije d. d. od 2009. godine u stanju konzervacije ili povremene proizvodnje, pojavila se mogućnost njihova uvođenja za proizvodnju novog proizvoda. Uvođenjem novog proizvoda provedena je revitalizacija postrojenja za proizvodnju granuliranih kompleksnih gnojiva NPK/MAP te je omogućena kontinuirana proizvodnja sumporne kiseline. Prednosti navedenih aktivnosti su uvođenje novog komercijalno i tržišno atraktivnog proizvoda u proizvodni asortiman Petrokemije d. d. te poboljšanje energijske učinkovitosti cjelokupnog proizvodnog kompleksa zbog iskorištenja otpadne topline reakcije tijekom proizvodnje sumporne kiseline.

Jedan od osnovnih ciljeva projekta sastojao se u osposobljavanju postojeće opreme postrojenja. Namjera je bila proizvodnja granuliranih kompleksnih mineralnih gnojiva NPK/MAP za potrebe proizvodnje sintetičkog granuliranog amonijeva sulfata s proizvodnim kapacitetom $20 \mathrm{th}^{-1}$, uz primarno iskorištenje raspoložive, već ugrađene i/ili rezervne opreme, tako da se investicijski troškovi svedu na minimum. Početne aktivnosti projekta sastojale su se u izradi materijalno-energijske bilance, s obzirom na to da se izvorno projektirani podaci nisu mogli primijeniti. Izvorni projektirani podaci zasnivali su se na reakciji neutralizacije amonijaka i fosforne kiseline, za razliku od intenzivnije reakcije neutralizacije amonijaka i sumporne kiseline. Zbog toga se prilikom izrade materijalne bilance posebna pažnja 
morala posvetiti temperaturi u cijevnom reaktoru, koja se morala kontrolirati dodavanjem velike količine procesne i otpadne vode. Voda za odvođenje topline dodavala se u obliku procesne vode koja se upotrebljava za pranje otpadnih plinova (tzv. postupak "skrubiranja"). U slučaju nekontrolirane reakcije neutralizacije između amonijaka i sumporne kiseline dolazi do naglog povećanja temperature reakcijske smjese. To može izazvati ekstremne temperaturne i korozijske uvjete koji mogu uzrokovati oštećenje metalnih materijala iz kojih se inače izrađuju cijevni reaktori. Uslijed uvođenja velike količine vode radi kontrole temperature reakcije neutralizacije amonijaka i sumporne kiseline nastaje velika količina pare koju je potrebno odvesti iz rotirajućeg bubnja granulatora pomoću postojeće opreme (ventilatori, dimnjaci sustava za pranje otpadnih plinova). Materijalno-energijska bilanca za potrebe proizvodnje $20 \mathrm{th}^{-1}$ sintetičkog granuliranog amonijeva sulfata izrađena je uz uvažavanje svih prethodno navedenih čimbenika, pri čemu je odabrano temperaturno područje reakcije neutralizacije iznosilo od $150^{\circ} \mathrm{C}$ do $180^{\circ} \mathrm{C}$. U slučaju postizanja temperature reakcije iznad $210^{\circ} \mathrm{C}$, aktivira se alarmno-blokadni sustav koji uzrokuje prekid dotoka amonijaka i sumporne kiseline radi sprječavanja oštećenja materijala od kojeg je izrađen cijevni reaktor. Početni cijevni reaktor za proizvodnju sintetičkog amonijeva sulfata izrađen je od čeličnog materijala tipa 316 L. Međutim nakon probne proizvodnje u vremenu od 6 sati uz kontrolirane temperaturne uvjete dolazi do pojave intenzivnog oštećenja materijala kao što je prikazano na slici 3. Oštećenje materijala nastalo je uslijed korozivnog djelovanja smjese amonijeva sulfata i amonijeva bisulfita. Utvrđeno je da je empirijska brzina korozije veća od $7 \mathrm{~mm} / 24 \mathrm{~h}$.

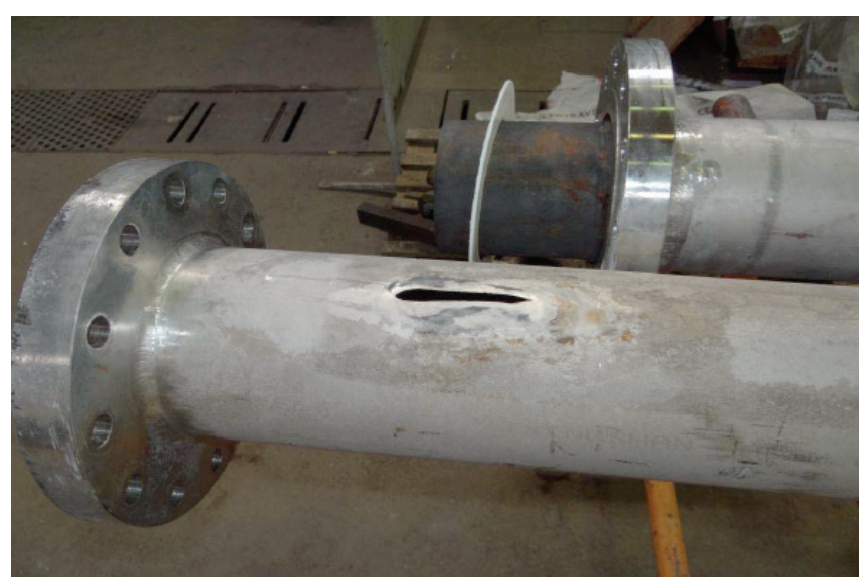

Slika 3 - Oštećenje materijala cijevnog reaktora uslijed korozivnog djelovanja smjese amonijeva sulfata $\mathrm{i}$ amonijeva bisulfita

Fig. 3 - Damage of pipe cross reactor material due to corrosive effect of ammonium sulphate and ammonium bisulphite slurry

Prilikom konstruiranja novog cijevnog reaktora uzete su u obzir sve relevantne činjenice koje se odnose na brzinu strujanja, tlakove i radne temperature, s posebnim naglaskom na mjesto doziranja amonijaka, sumporne kiseline, procesne vode te aditiva za poboljšanje procesa granulaci- je. Za razliku od izvorne izvedbe cijevnog reaktora, promijenjeni su ulazni položaji uvođenja svih procesnih medija, što se kasnijim kontinuiranim postupkom proizvodnje pokazalo ispravnim pristupom.

S obzirom na nastale okolnosti i činjenicu da tek neznatan broj iznimno egzotičnih i skupih metala pokazuje zadovoljavajuću otpornost u uvjetima intenzivne korozije, pristupilo se oblaganju cjelokupnog cijevnog reaktora drugim nemetalnim materijalima. Posebno odabranim materijalom te vlastito razvijenom tehnologijom oblaganja metalnog dijela cijevnog reaktora s ciljem zaštite od kontakta sa smjesom amonijeva sulfata i amonijeva bisulfita ostvareni su uvjeti za kontinuirani rad i omogućena je proizvodnja komercijalnih količina produkata bez obustave proizvodnog procesa zbog oštećenja materijala cijevnog reaktora.

S obzirom na to da je postupak granulacije sintetički proizvedenog amonijeva sulfata iznimno zahtjevan u pogledu dodavanja odgovarajućeg aditiva kao promotora nastanka granula, bilo je potrebno odabrati odgovarajući aditiv te razviti postupak njegova dodavanja. Kao aditiv za postupak granulacije odabran je spoj koji sadrži trovalentni metal u obliku sulfata, koji se često upotrebljava u različitim postupcima uklanjanja nečistoća prilikom industrijske obrade vode u flokulatorima. Položaj i način dodavanja aditiva u reakcijski tok izveden je tako da se omogući kontinuirano dodavanje uz postizanje zadovoljavajućih fizikalnih svojstava gotovog materijala. Osim razvijenog postupka dodavanja aditiva, posebna pažnja mora se posvetiti količini proizvoda koji se povratno vraća u rotirajući bubanj granulatora, čija funkcija je generiranje dovoljno polaznog materijala za primjenu smjese amonijeva sulfata i amonijeva bisulfita nastalog u cijevnom reaktoru. Za pravilan postupak granulacije omjer između povratnog materijala u rotirajućem bubnju granulatora i izlazne smjese amonijeva sulfata i amonijeva bisulfita iz cijevnog reaktora mora biti u području od $7: 1$ do $5: 1$. U slučaju lošeg odabira aditiva i odgovarajućeg sustava za njegovo doziranje te narušavanja omjera između povratnog materijala i novonastale smjese dolazi do nastanka velike količine prašine koju je nemoguće odgovarajućim postupcima prevesti u granulirani oblik. Pravilnim podešavanjem navedenih procesnih parametara omogućena je proizvodnja pravilnih i sferičnih granula amonijeva sulfata izuzetnih fizikalnih značajki.

S obzirom na to da većina izvorno projektirane mjerno-regulacijske opreme nije zadovoljavala uvjete prema izrađenoj materijalno-energijskoj bilanci, pristupilo se njezinoj prenamjeni, što je provedeno uz minimalna novčana ulaganja u vlastitim radionicama za održavanje. Postupak prenamjene nakon puštanja u rad pokazao se iznimno zadovoljavajućim, što je omogućilo kontinuirano i stabilno doziranje svih procesnih medija u cijevni reaktor.

Granulirani amonijev sulfat osobito je pogodan za postupak namješavanja s ostalim jednostavnim mineralnim gnojivima u pogledu fizikalne i kemijske stabilnosti, što je vidljivo iz slike $4 .^{1}$

$\mathrm{U}$ jednostavnim granuliranim mineralnim gnojivima maseni udjel granula dimenzija od 2 do $5 \mathrm{~mm}$ mora biti veći od $95 \%$, s posebnim naglaskom na sferičnost granula, što im uz veliku čvrstoću, malu sklonost prema stvrdnjavanju i 


\begin{tabular}{|c|c|c|c|c|c|c|c|c|}
\hline & 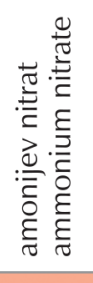 & & \multirow{3}{*}{ 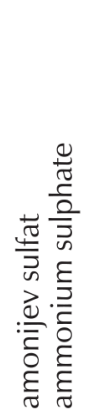 } & \multirow{4}{*}{ 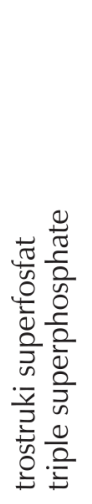 } & \multirow{5}{*}{ 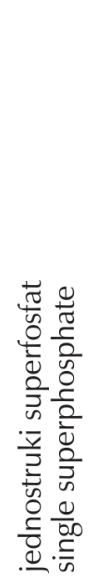 } & \multirow{6}{*}{ 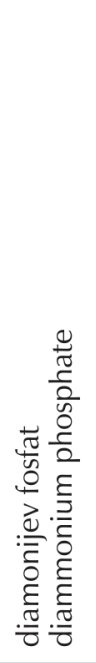 } & \multirow{7}{*}{ 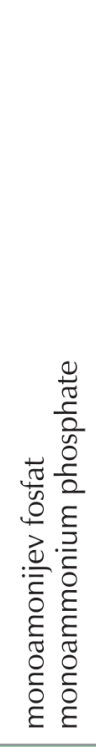 } & \multirow{8}{*}{ 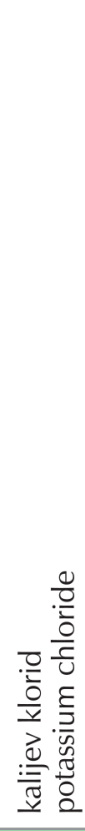 } \\
\hline $\begin{array}{l}\text { urea } \\
\text { urea }\end{array}$ & $x$ & $\stackrel{\Xi}{\Xi}$ & & & & & & \\
\hline $\begin{array}{l}\text { amonijev sulfat } \\
\text { ammonium sulphate }\end{array}$ & OK & OK & & & & & & \\
\hline $\begin{array}{l}\text { trostruki superfosfat } \\
\text { triple superphosphate }\end{array}$ & OK & L & OK & & & & & \\
\hline $\begin{array}{l}\text { jednostruki superfosfat } \\
\text { single superphosphate }\end{array}$ & OK & L & OK & OK & & & & \\
\hline $\begin{array}{l}\text { diamonijev fosfat } \\
\text { diammonium phosphate }\end{array}$ & OK & OK & OK & L & L & & & \\
\hline $\begin{array}{l}\text { monoamonijev fosfat } \\
\text { monoammonium phosphate }\end{array}$ & OK & OK & OK & OK & OK & OK & & \\
\hline $\begin{array}{l}\text { kalijev klorid } \\
\text { potassium chloride }\end{array}$ & OK & OK & OK & OK & OK & OK & OK & \\
\hline $\begin{array}{l}\text { kalijev sulfat } \\
\text { potassium sulphate }\end{array}$ & OK & OK & OK & OK & OK & OK & OK & OK \\
\hline
\end{tabular}

Slika 4 - Fizikalno-kemijska stabilnost smjesa jednostavnih mineralnih gnojiva (X - nestabilna smjesa; L ograničeno stabilna smjesa; OK - stabilna smjesa)

Fig. 4 - Physicochemical stability of blend materials ( $\mathrm{X}$ - unstable mixture; $\mathrm{L}$ - limited stable mixture; OK - stable mixture)

habanju omogućava miješanje i čini ih ekonomski prihvatljivim u odnosu na kompleksna granulirana mineralna gnojiva. Najveći utjecaj na ujednačenost i oblik granula postiže se postupkom granulacije pomoću rotirajućeg bubnja granulatora. Pri tome je potrebno voditi računa o sljedećim procesnim parametrima:

1. temperaturi i tlaku smjese amonijeva sulfata i amonijeva bisulfita na izlazu iz cijevnog reaktora

2. vrsti i načinu dodavanja aditiva tijekom postupka granulacije

3. omjeru povratne količine usitnjenog amonijeva sulfata $i$ količine nove smjese amonijeva sulfata i amonijeva bisulfita na izlazu iz cijevnog reaktora

4. temperaturi granula na izlazu iz rotirajućeg bubnja granulatora

5. broju okretaja rotirajućeg bubnja granulatora

6. brzini uklanjanja prašine i nastale pare iz rotirajućeg bubnja granulatora tijekom procesa granulacije te reakcije neutralizacije amonijaka i sumporne kiseline.

U daljnjem postupku proizvodnje granuliranog amonijeva sulfata na granulometrijski sastav gotovog proizvoda može se dodatno utjecati sustavom prosijavanja. Sustavom prosijavanja odvajaju se granule manje od $2 \mathrm{~mm}$ i veće od
$5 \mathrm{~mm}$. Granule manje od $2 \mathrm{~mm}$ usmjeravaju se izravno u rotirajući bubanj granulatora, dok se granule veće od $5 \mathrm{~mm}$ usmjeravaju na sustav mlinova, gdje se usitnjavaju na veličinu manju od $2 \mathrm{~mm}$ i ponovno vraćaju u rotirajući bubanj granulatora. Jedna i druga frakcija primjenjuju se kao povratni materijal koji određuje omjer u postupku granulacije. Kako bi se postigao što ujednačeniji proizvod granulometrijskog sastava (tj. > $95 \%$ u području veličina od 2 do $5 \mathrm{~mm}$ ), proveden je postupak zamjene postojećih dimenzija otvora sita s dimenzijom koja je omogućila postizanje očekivanih svojstava.

Pojednostavljena procesna shema cjelokupnog procesa proizvodnje granuliranog amonijeva sulfata prikazana je na slici 5.

Radovi vezani uz prenamjenu i održavanje na postojećoj opremi provedeni su u razdoblju od 2. 1. 2015. do 6. 3. 2015. Prva probna proizvodnja $1000 \mathrm{t}$ granuliranog amonijeva sulfata provedena je u razdoblju od 6. 3. 2015. do 31. 3. 2015. uz značajne probleme vezane uz oštećenje materijala od kojeg je izrađen cijevni reaktor. Nova količina komercijalnog proizvoda od 5000 t proizvedena je od 20. 5. 2015. do 31. 5. 2015. uz minimalne zastoje, koji su većinom bili povezani s ostalom opremom u postrojenju. Fizikalno-kemijske značajke ukupno proizvedene količine granuliranog amonijeva sulfata prikazane su u tablici 1 , gdje je vidljivo da su postignuta sva tražena 


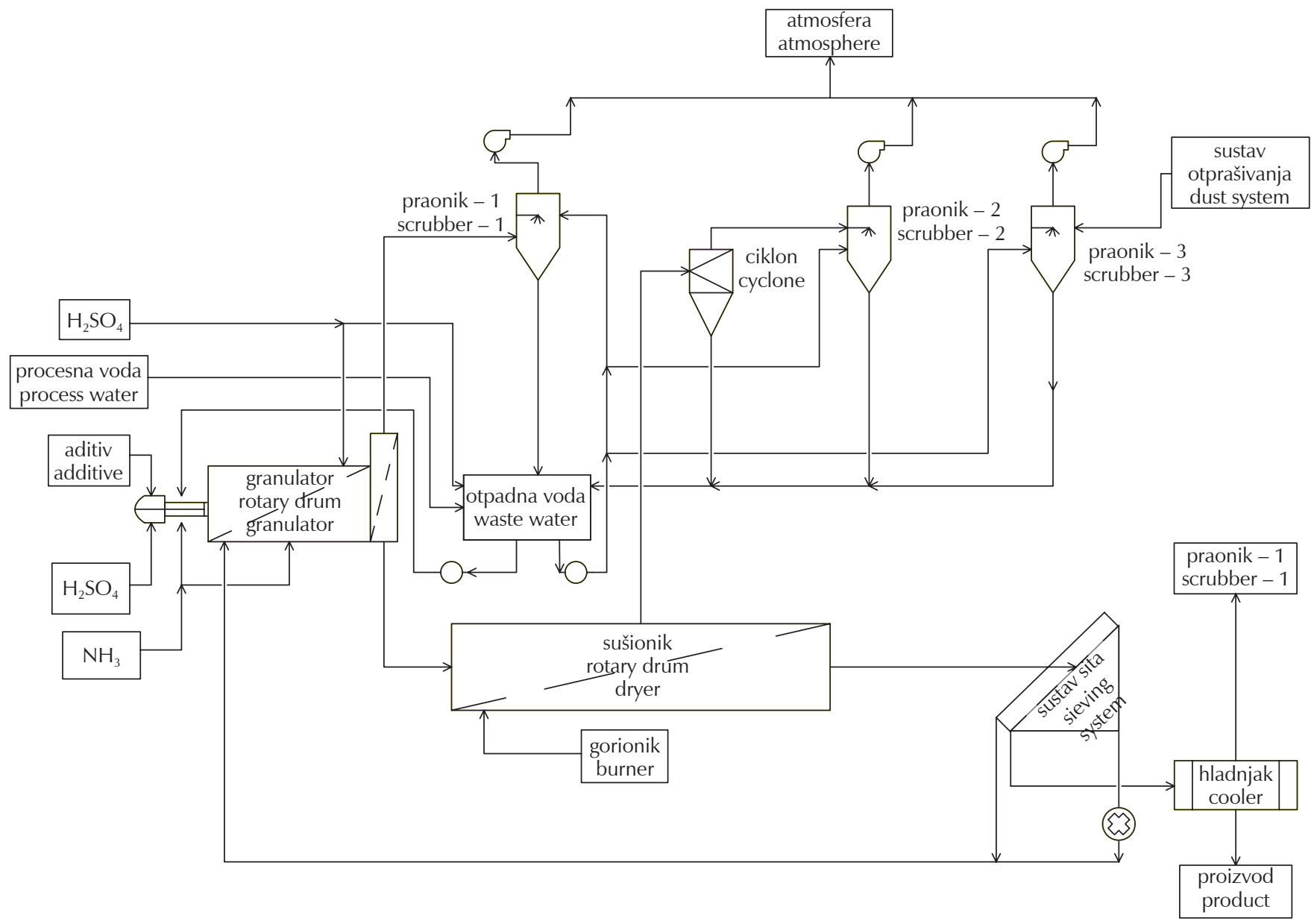

Slika 5 - Procesna shema postrojenja za proizvodnju sintetičkog granuliranog amonijeva sulfata

Fig. 5 - Process scheme for preparation of synthetic granulated ammonium sulphate

svojstva komercijalnog proizvoda. U tablici 2 prikazan je odnos između planiranih i ostvarenih utrošaka sirovina i energije pri proizvodnom kapacitetu $20 \mathrm{t} \mathrm{h}^{-1}$, iz kojeg je vidljivo da su zadovoljeni svi procesni parametri osim potrošnje prirodnog plina u procesu sušenja gotovog proizvoda. Navedena razlika u odnosu na planiranu količinu je zbog sušenja gotovog proizvoda na maseni udjel vlage ispod 0,50 \%. Navedeni sadržaj vlage u odnosu na druga mineralna gnojiva znatno je niži, budući da pri sadržaju vlage koji je uobičajen za druga mineralna gnojiva (oko $1,00 \%$ granulirani amonijev sulfat pokazuje povećanu sklonost prema stvrdnjavanju. Sa sadržajem vlage ispod $0,50 \%$ granulirani amonijev sulfat pokazuje sklonost prema stvrdnjavanju ispod $5 \mathrm{~N}$, što je izniman rezultat koji garantira dobra skladišna svojstva tijekom duljeg razdoblja, bilo u rasutom stanju, bilo u zapakiranom obliku u polietilenskim materijalima.

Na slici 6 prikazan je izgled granuliranog amonijeva sulfata. Proizvod je bijele boje, pravilnih sferičnih granula bez sklonosti prema stvrdnjavanju i stvaranju prašine te velike čvrstoće, što mu daje iznimna transportna i skladišna svojstva. U kombinaciji s drugim jednostavnim mineralnim gnojivi- ma pokazuje iznimnu kompatibilnost, što omogućava njegovu komercijalnu primjenu u postupcima namješavanja.

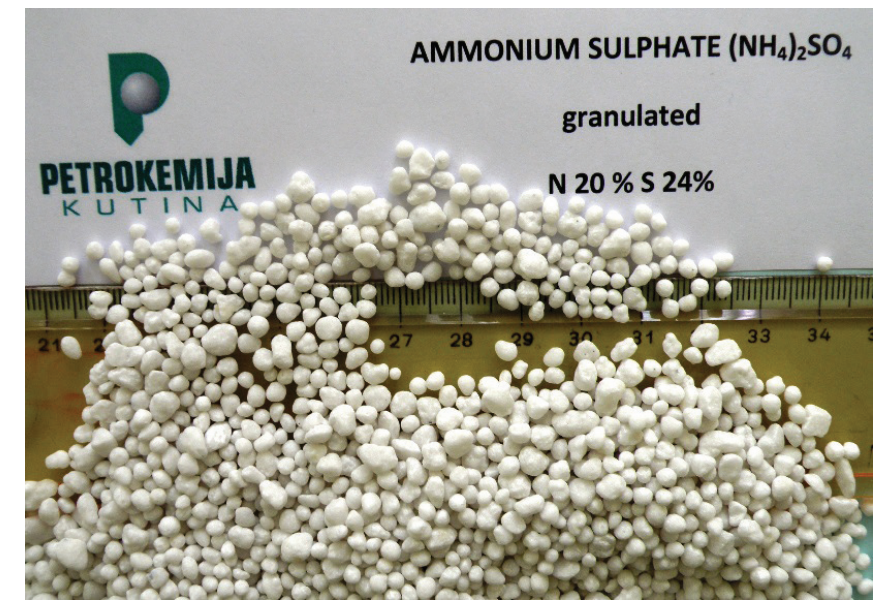

Slika 6 - Granulirani amonijev sulfat

Fig. 6 - Granulated ammonium sulphate 
Table 1 - Fizikalno-kemijska svojstva granuliranog $\left(\mathrm{NH}_{4}\right)_{2} \mathrm{SO}_{4}$ Tablica 1 - Physicochemical properties of granulated $\left(\mathrm{NH}_{4}\right)_{2} \mathrm{SO}_{4}$

\begin{tabular}{|c|c|}
\hline $\begin{array}{l}w(\text { ukupni dušik) } / \% \\
w(\text { total nitrogen }) / \%\end{array}$ & 20,08 \\
\hline $\begin{array}{l}w(\text { ukupni sumpor) } / \% \\
w(\text { total sulphur }) / \%\end{array}$ & 23,68 \\
\hline $\begin{array}{l}w(\text { aditiv za granulaciju }) / \% \\
w(\text { granulation additive }) / \%\end{array}$ & 0,37 \\
\hline $\begin{array}{l}w(\text { vlaga }) / \% \\
w(\text { moisture }) / \%\end{array}$ & 0,33 \\
\hline$w(d>5 \mathrm{~mm}) / \%$ & 1,3 \\
\hline$w(3,35 \mathrm{~mm}<d<5 \mathrm{~mm}) / \%$ & 23,1 \\
\hline$w(2 \mathrm{~mm}<d<3,35 \mathrm{~mm}) / \%$ & 70,8 \\
\hline$w(1 \mathrm{~mm}<d<2 \mathrm{~mm}) / \%$ & 4,8 \\
\hline$w(d<1 \mathrm{~mm}) / \%$ & 0,0 \\
\hline $\begin{array}{l}w(\text { sredstvo protiv stvrdnjavanja) } / \% \\
w(\text { anti-caking agent) } / \%\end{array}$ & 0,115 \\
\hline $\begin{array}{l}\text { čvrstoća granula / bar } \\
\text { granule strength / bar }\end{array}$ & 64 \\
\hline $\begin{array}{l}w(\text { habanje granula }) / \% \\
w(\text { granule attrition }) / \%\end{array}$ & 0,52 \\
\hline $\begin{array}{l}w(\text { prašina }) / \% \\
w(\text { dust }) / \%\end{array}$ & 0,08 \\
\hline $\begin{array}{l}F(\text { stvrdnjavanje }) / \mathrm{N} \\
F(\text { caking }) / \mathrm{N}\end{array}$ & 3 \\
\hline$\rho / \mathrm{kg} \mathrm{m}^{-3}$ & 950 \\
\hline
\end{tabular}

\section{Zaključak}

Kompleksna mineralna gnojiva NPK u sve većoj mjeri zamjenjuju se jednostavnim mineralnim gnojivima te njihovim mješavinama. Proizvedeni granulirani amonijev sulfat kao jednostavno mineralno gnojivo posjeduje izniman potencijal u postupcima namješavanja, budući da ima iznimna fizikalna svojstva. Osim toga, sadrži i sumpor kao dodatni element u poljoprivrednoj proizvodnji. S obzirom na to da je u proizvodnom kompleksu za proizvodnju mineralnih gnojiva Petrokemije $\mathrm{d}$. d. postojala mogućnost pokretanja proizvodnje granuliranog amonijeva sulfata kao potpuno novog proizvoda, pokrenut je niz aktivnosti s ciljem omogućavanja proizvodnje. Na postrojenju za proizvodnju kompleksnih granuliranih mineralnih gnojiva NPK i MAP, koje je bilo u povremenoj proizvodnji, provedene su preinake, što je omogućilo proizvodnju granuliranog amonijeva sulfata. Primjenom vlastitog znanja projektiran je cijevni reaktor izrađen od metala i izoliran nemetalnim materijalom s ciljem kontinuiranog odgovora zahtjevima egzotermne i korozivne reakcije neutralizacije amonijaka i sumporne kiseline. Da bi se postigla ujednačena granulacija i komercijalno tražene fizikalne značajke proizvoda, razvijen je sustav dodavanja aditiva tijekom procesa granulacije. Isto tako, unutar postojećeg postrojenja provedene su promjene na opremi kojom se prosijava gotov proizvod. Minimalnim financijskim ulaganjima postojeće postrojenje prenamijenjeno je za proizvodnju granuliranog amonije-
Table 2 - Planirani i ostvareni utrošci sirovina i procesnih medija za proizvodnju granuliranog amonijeva sulfata

Tablica 2 - Planned and achieved consumptions of raw materials and utilities for production of granulated ammonium sulphate

\begin{tabular}{|c|c|c|c|}
\hline $\begin{array}{l}\text { Sirovina i procesni medij } \\
\text { Raw material and utility }\end{array}$ & $\begin{array}{l}\text { Planirano } \\
\text { Planned }\end{array}$ & $\begin{array}{l}\text { Ostvareno } \\
\text { Achieved }\end{array}$ & $\begin{array}{l}\text { Odnos } \\
\text { Ratio }\end{array}$ \\
\hline $\begin{array}{l}m \text { (amonijak) } / \mathrm{t} \\
m(\text { ammonia }) / \mathrm{t}\end{array}$ & 0,259 & 0,233 & 89,77 \\
\hline $\begin{array}{l}m \text { (sumporna kiselina) } / \mathrm{t} \\
m(\text { sulphuric acid }) / \mathrm{t}\end{array}$ & 0,753 & 0,642 & 85,27 \\
\hline $\begin{array}{l}m \text { (aditiv za granulaciju) } / \mathrm{t} \\
m \text { (granulator additive }) / \mathrm{t}\end{array}$ & 0,036 & 0,038 & 104,27 \\
\hline$W_{\mathrm{el}} / \mathrm{MWh}$ & 0,045 & 0,045 & 100,00 \\
\hline $\begin{array}{l}m(\text { para } 12 \text { bar }) / t \\
m(\text { steam } 12 \text { bar }) / t\end{array}$ & 0,050 & 0,041 & 82,69 \\
\hline $\begin{array}{l}m(\text { para } 4 \text { bar }) / t \\
m(\text { steam } 4 \text { bar }) / t\end{array}$ & 0,030 & 0,030 & 100,00 \\
\hline $\begin{array}{l}V_{\text {ISO }}(\text { prirodni plin }) / \mathrm{m}^{3} \\
V_{\text {ISO }}(\text { natural gas }) / \mathrm{m}^{3}\end{array}$ & 9,000 & 22,792 & 253,25 \\
\hline $\begin{array}{l}m(\text { procesna voda }) / t \\
m(\text { process water }) / t\end{array}$ & 0,550 & 0,550 & 100,00 \\
\hline $\begin{array}{l}V_{\text {ISO }}(\text { instrumentni zrak }) / \mathrm{m}^{3} \\
V_{\text {ISO }}(\text { instrument air }) / \mathrm{m}^{3}\end{array}$ & 20,00 & 20,000 & 100,00 \\
\hline $\begin{array}{l}m \text { (sredstvo protiv stvrdnjavanja) } / \mathrm{kg} \\
m(\text { anti-caking agent }) / \mathrm{kg}\end{array}$ & 1,500 & 1,430 & 95,51 \\
\hline
\end{tabular}

va sulfata u količini $20 \mathrm{th}^{-1}$. Postignuta fizikalno-kemijska svojstva dobivenog proizvoda zadovoljavaju sve tražene zahtjeve, kako u pogledu samostalne primjene kao jednostavnog mineralnog gnojiva tako i u pogledu mogućeg namješavanja s ostalim jednostavnim mineralnim gnojivima. Dobivenim proizvodom omogućeno je proširenje proizvodnog asortimana Petrokemije d. d. uz istodobno poboljšanje energijske učinkovitosti proizvodnog kompleksa budući da je omogućena kontinuirana proizvodnja sumporne kiseline i uporaba nastale otpadne topline.

\section{Popis kratica i simbola List of abbreviations and symbols}

MAP - monoamonijev fosfat - monoammonium phosphate

NPK - dušik, fosfor, kalij - nitrogen, phosphorus, potassium

$\Delta H \quad$ - promjena entalpije, $\mathrm{kJ} \mathrm{kg}^{-1}$

- enthalpy change, $\mathrm{kJ} \mathrm{kg}^{-1}$

d - promjer granule, $\mathrm{mm}$

- granule diameter, mm

F - sklonost prema stvrdnjavanju, $\mathrm{N}$

- caking tendency, $\mathrm{N}$

m - masa, $\mathrm{t}, \mathrm{kg}$

- mass, t, kg 
$V_{\text {ISO }} \quad$ - obujam plina pri standardnim referentnim uvjetima $\left(101,325 \mathrm{kPa}, 15^{\circ} \mathrm{C}\right)$

- volume of gas at standard reference conditions $\left(101,325 \mathrm{~Pa}, 15^{\circ} \mathrm{C}\right)$

$W_{\text {el }} \quad$ - električna energija, $M W h$

- electrical energy, MWh

w $\quad-$ maseni udjel, $\%$

- mass content, \%

- nasipna gustoća, $\mathrm{kg} \mathrm{m}^{-3}$

- bulk density, $\mathrm{kg} \mathrm{m}^{-3}$

\section{Literatura \\ References}

1. United Nations Industrial Development Organization (UNIDO), Fertilizer Manual, Kluwer Academic Publisher, 1998. str. 242-248.

2. D. M. Ivell, T. Brown, Real Granular Ammonium Sulphate at
Fertinal, Mexico, Proceedings of the $49^{\text {th }}$ Annual Meeting Fertilizer Industry Round Table, Lake Buena Vista, Florida, USA, 1999., str. 29-37.

3. M. Fischbein, T. Brown (Incitec Pivot), High quality granular ammonium sulphate production, International Fertilizer Association, Paris, France, 1988., str. 1-14.

4. W. Burns (Shell), Ammonium Sulphate - Ammonium Bisulphate Fertilizer and Method of Making, U.S. Patent 3,351,455, (1967)

5. G. Hicks, Process for Production of Granular Ammonium Sulphate Process, J. Agric. Food Chem. 17 (1978) 786-797.

6. J. Harrison (Incitec Pivot), Granulation of Crystalline By-Product Ammonium Sulphate, U.S. 4,589,904, (1986).

7. D. Bellis (Biomihania Fosforikon), Method for the preparation of granulated ammonium sulphate, EP 1067093 A1, (2001).

8. R. Ingles (Yara International SA), Method for producing fertilizer containing urea and ammonium sulphate, U.S. 7.837,787 B2, (2010)

\title{
EXTENDED ABSTRACT
}

\author{
Preparation of Synthetic Granulated Ammonium Sulphate \\ Nenad Zečević,a* Mate Ljubičić,a Jovan Bjelić,a Hrvoje Lisac, a and Svetoslav Valkov ${ }^{b}$
}

\begin{abstract}
According to its original design, the plant for production of granulated NPK complex fertilizers and granulated MAP as well, within the manufacturing complex of Petrokemija Plc., was not envisaged for the production of synthetic granulated ammonium sulphate. Revamping of the facility into a pipe cross reactor and rotary drum granulator with the use of sulphuric acid and liquid ammonia has enabled the production of synthetic granulated ammonium sulphate. The main changes and activities performed at the existing facility are shown in Fig. 2. Regarding the remarkable exothermic and corrosive potential of the neutralization reaction between ammonia and sulphuric acid, a proprietary technology has been developed through the specifically derived pipe cross reactor, providing safe and continuous operation with production capacity of $20 \mathrm{th}^{-1}$. The original metal for the pipe cross reactor was inadequate for continuous operation due to extremely intensive corrosion propagation of ammonium sulphate slurry. The impact of the described effect is shown in Fig. 3. Together with the application of the pipe cross reactor, it a method for using a special additive for the purpose of the granulation process has also been developed, because without it, the ammonium sulphate could not be converted into granular shape. The overall process scheme for the preparation of granulated ammonium sulphate is shown in Fig. 5. The physicochemical quality of the produced ammonium sulphate in relation to all required characteristics is extremely satisfactory compared to other types of complex fertilizers, which can be observed in Table 1. Table 2 shows the consumption of raw materials and utilities during preparation of granulated ammonium sulphate. An image of the shape of the granulated ammonium sulphate is presented in Fig. 6 . The developed granulated ammonium sulphate production process is classified as a new product in the production portfolio of complex fertilizers of Petrokemija Plc., with special emphasis on usage in a blending procedure with other straight fertilizers.
\end{abstract}

Keywords

Additive, ammonium sulphate, granulation, pipe cross reactor

a Petrokemija PlC., 44320 Kutina, Croatia

bSNC Lavalin, 1050 Brussels, Belgium

Professional paper

Received June 9, 2015

Accepted September 2, 2015 